\title{
The southern Jê and adaptation to the wetland areas on the southern of the Araucarias plateau/Brazil
}

The Jê archeology has witnessed in the last decades a significant increase in information on the pattern of settlement, subsistence, mobility and ceremonia practices as a result of major projects developed in the South Brazilian Plateau. With the beginning of a systemic and procedural view in archeology, interdisciplinary studies in archaeological research are directed to the study on the understanding of human relations with the environment. Between the basins of the Forqueta and Guaporé Rivers, both tributaries of the right bank of the Taquari/Antas River, twenty-one archaeological sites were found with the presence of pit houses associated with Jê groups. Of the twenty-one areas of identified pit houses, nineteen are in areas close to wetlands. In an interdisciplinary perspective, we seek to understand the reasons why Jê groups established settlements close to wetlands. Six criteria were analyzed regarding the installation of pit houses and the proximity to wetlands, namely hydrography, distance from rivers with running water, clinography, terrain slope, hypsometry, altitude in relation to sea level, soils, soil quality, distance from wetlands, and phytoecological region (vegetation cover). The patterns of occupation of Jê groups were analyzed using the Principal Component Analysis technique on the variables presented.

Keywords: Archeology; Atlantic Forest; Human Ecology; Pit House.

\section{O sul do Jê e adaptação às áreas úmidas do sul do planalto das Araucárias/Brasil}

\begin{abstract}
A arqueologia Jê tem testemunhado nas últimas décadas um aumento significativo de informações sobre o padrão de ocupação, subsistência, mobilidade e práticas cerimoniais em decorrência de grandes projetos desenvolvidos no Planalto Sul Brasileiro. Com o início de uma visão sistêmica e procedimental na arqueologia, os estudos interdisciplinares na pesquisa arqueológica são direcionados ao estudo da compreensão das relações humanas com o meio ambiente. Entre as bacias dos rios Forqueta e Guaporé, ambos afluentes da margem direita do rio Taquari/Antas, foram encontrados 21 sítios arqueológicos com presença de fossas associadas aos grupos Jê. Das vinte e uma áreas de fossas identificadas, dezenove estão em áreas próximas a pântanos. Numa perspectiva interdisciplinar, buscamos compreender os motivos pelos quais grupos de Jê estabeleceram assentamentos próximos a áreas úmidas. Seis critérios foram analisados em relação à instalação de fossas e a proximidade de zonas húmidas, nomeadamente hidrografia, distância de rios com água corrente, clinografia, declive do terreno, hipsometria, altitude em relação ao nível do mar, solos, qualidade do solo, distância de zonas húmidas, e região fitoecológica (cobertura vegetal). Os padrões de ocupação dos grupos Jê foram analisados por meio da técnica de Análise de Componentes Principais sobre as variáveis apresentadas.
\end{abstract}

Palavras-chave: Arqueologia; Mata Atlântica; Ecologia humana; Pit House.

Topic: Geografia Regional

Reviewed anonymously in the process of blind peer.
Received: 06/03/2021

Approved: 22/03/2021
Jones Fiegenbaum (D)

Universidade do Vale do Taquari, Brasil http://lattes.cnpq.br/5224988036145533 http://orcid.org/0000-0003-4029-451X

jones@universo.univates.br

Marina Schmidt Dalzochio

Universidade Feevale, Brasil

http://lattes.cnpq.br/8400882066099257

http://orcid.org/0000-0001-9241-921X

mahsdalzochio@gmail.com

\section{Eduardo Périco (D)}

Universidade do Vale do Taquari, Brasil

http://lattes.cnpq.br/4494244221645524

http://orcid.org/0000-0002-2926-6246

perico@univates.br
Neli Teresinha Galarce Machado (iD)

Universidade do Vale do Taquari, Brasil

http://lattes.cnpq.br/6666207712034183

http://orcid.org/0000-0003-1209-5353

ngalarce@univates.br
Referencing this:

FIEGENBAUM, J.; DALZOCHIO, M. S.; PÉRICO, E.; MACHADO, N. T. G.. The southern Jê and adaptation to the wetland areas on the southern of the Araucarias plateau/Brazil. Revista Ibero Americana de Ciências Ambientais, v.12, n.3, p.737-747, 2021. DOI: http://doi.org/10.6008/CBPC2179-6858.2021.003.0058 


\section{INTRODUCTION}

The contribution of environmental archeology rebukes the precepts present by Renfrew et al. (1993) in establishing relationships between humans and the environment. Vegetation, relief, water resources, vegetation cover and distance from wetlands are selected as factors that can contribute to the identification of strategic ways to adapt to the environment.

In the context of human ecology, adaptation does not refer to a passive accommodation or submission to the limits of the environment (biological and cultural), but rather to strategies in the exploration of natural resources in an effort to maintain and reproduce the way of life of these groups (DROUIN, 1991; LADURIE, 1991; MARTINS, 1994; MORAN, 1994; SIEMENS, 1999; WORSTER, 2003).

The territory recognized as the Jê group extends over a vast and ecologically diverse region from the Atlantic coast to the Paraná River in areas inside the Brazilian states of Mato Grosso do Sul, São Paulo, Paraná, Santa Catarina and Rio Grande do Sul, in addition to the Argentine province of Misiones (NOELLI, 2004). In general, this region is composed of four ecotones: on the Atlantic coast, the coastal plain with lagoons and sandbanks; a little inland, the hillside with valleys forested by the Atlantic Forest; at the top of the mountains, the plateau with fields and Brazilian pine (araucaria); and further west, where altitudes decrease again, the valleys of the subtropical forest (CORTELETTI et al., 2018).

In the last decades, some syntheses have been carried out and the patterns of establishment, territoriality and mobility of these people were studied. In these divisions, three currents of thought are proposed about the group's settlements. A first set of authors proposes distinctions about territoriality based on high seasonal mobility, in which subsistence would be due to the exploration of collection and hunting in different environments in addition to the possible practice of agriculture (SCHMITZ et al., 1991; BEBER, 2005; SCHMITZ et al., 2011b; WOLF, 2016), another group of authors believes in a high vertical mobility across the three environments but presents evidence that a differentiated system may have occurred (REIS, 1997; DIAS, 2003), finally, a third group of authors reinforces the existence of social units in which mobility is lower and does not need large-scale seasonal migrations to maintain subsistence (ROBRAHN, 1989; SALDANHA, 2005; DEMASI, 2005; COPÉ, 2006a; 2006b; ARAÚJO, 2001; 2007; SOUZA et al., 2016a; 2016b).

The proximity of underground structures to wetlands is reported in previous works (REIS, 1980; 2002; 2007; ROGGE et al., 2009; COPÉ, 2015). Novasco et al. (2016) demonstrated that the building of houses took place respecting the strategies they considered and sought a proximity to water resources. The arrangement of structures allows supposing that the high-altitude wetlands and the water flow, which cuts through the site, are the catalyst elements of occupations. It is noticed that the houses are arranged on areas not far from water sources, concentrating mainly around the water flow and the wetland with river accumulation.

However, this relationship between the agents that build pit houses and the wetlands is still little discussed. Rogge et al. (2009) described the environmental characteristics of areas they surveyed in the municipality of São Marcos (RS) and reported that in the negative undulations of broad levels, where the levels vary between 700 and 800 meters, there are wetlands that give rise to small water courses that flow 
into the Antas River, and close to these streams are the sites with pit houses. Copé (2015) reported the same settlement pattern in sites identified by her in the municipalities of Bom Jesus and Pinhal da Serra. According to the author, in the valleys of the Pelotas River and the Antas River, the sets of pit houses occupy the highest parts of the plateau, located close to the sources of tributaries of the aforementioned rivers.

In previous research carried out in Boa Parada, also in the municipality of São José do Cerrito, the same pattern was found. In that context, the structures are within the orbit of the wetland and the cemetery, demonstrating that the source of subsistence resources and the ceremonial spaces divide the center of the pit houses' implantation area (SCHMITZ et al., 2011a).

According presented information, the present work is guided by the precepts of environmental archeology (BUTZER, 1982; EVANS, 1978; DEAGEN, 1996; REITZ et al., 1996; KORMONDY et al., 2002; SCHUTKOWSKI, 2006) together with elements of Human Ecology (CASTRO, 2004; ADAMS et al., 2006). These currents of thought are a theoretical basis to support the conceptual precepts and later the interpretations generated in the work the Jê Group between the basins of the Forqueta and Guapore Rivers in the central eastern portion of the state of Rio Grande do Sul, Brazil. These ecosystems are well known in archeology literature for their use by other past groups, such as the builders of knolls and deposit of shells, but studies associating these areas with the Jê Group are unprecedented.

From the perspective of an occupation with less mobility, this article presents a new possibility of subsistence to be explored by this group. The wetlands have potential and variability of fauna and flora resources that can be used throughout the year, ensuring this group another variable in forest management and the use of an ecosystem found in abundance in the studied landscape.

\section{MATERIALS AND METHODS}

\section{Study Area}

This research focuses on the archeological areas identified in a stripe between the hydrographic basins of the Forqueta and Guaporé Rivers, located in the northeast portion of the state of Rio Grande do Sul/Brazil.

The surveys were carried out by this study and previous prospecting and excavation works (MACHADO et al., 2005; WOLF, 2016). Seventy points were highlighted with the presence of archaeological material and characteristics of archaeological sites composed of underground and semi-pit houses, open sky sites, and mounds. The archaeological evidence is associated with the Jê Group.

Among the archaeological occurrences identified in the region, the twenty-one sites with pit houses are close to wetlands. This surrounding between the underground structures and the aforementioned ecosystem motivates the present study in establishing subsidies that support an interaction between the Jê Group and the wetlands, thus composing another element in the agroforestry management that the group carries out.

The twenty-one underground structures are located geomorphologically in the Araucaria Plateau. 
This area presents an environment with significant differences in relief and vegetation, which allows the meeting of different spaces in a short distance. Water resources, although different, have similarities throughout their course. In an area that corresponds to $9 \%$ of the state's territory, the rivers are secondorder tributaries with characteristics of elongated basins and meandering courses (PERICO et al., 2011).

The vegetation formation follows the dynamics of the relief in the course of the rivers because, next to streams, they present a vegetation formation characterized by the presence of a field/forest mosaic, with predominance of examples of the Mixed Rainforest (MOF), a flat relief with small elevations, and altitudes that can reach $900 \mathrm{~m}$. In its intermediate course, there is a valley marked by a deepening next to the Serra Geral Formation of basaltic rocks in a V shape, occasionally with flat formations in the vicinity of water resources, and altitudes ranging between 350 and 700 m, covered at their lowest areas with a seasonal deciduous forest, while at altitudes above $400 \mathrm{~m}$, there is a predominance of the MOF. Next to the outfall of the Taquari-Antas River, the relief is dominated by flood plains of up to $120,000 \mathrm{~m}^{2}$ covered by waters in periods of flood with a predominance of deciduous seasonal forest (TEIXEIRA et al., 1986).

\section{Data collection and analysis}

The methodology is divided between the criteria chosen for data collection in landscape and data analysis. The criteria were adapted from the work of Kreutz (2015). The author determined favorable conditions for the establishment of the Guarani group in the Taquari/Antas River basin from environmental characteristics for the location of archaeological sites. The information was collected from the database provided by Instituto Brasileiro de Geografia e Estatística (IBGE, 2010) and the images were produced using the software ArcGIS.

The criteria selected with their respective definition are lotic ecosystem, distance from nearest rivers, smaller tributaries and streams in relation to archaeological sites; wetlands, distance from nearest wetlands in relation to archaeological sites; slope, clinography of the terrain where the archaeological sites are located; altimetry, altitude in relation to the sea level of the places where the archaeological sites are; pedology, soil classes where archaeological sites are found; and vegetable cover, phytoecological region, where archaeological sites are located. These data were organized in a table that includes each variable in relation to the analyzed sites (Table 1).

Table 1: Variables observed for each site analyzed. All distances are stipulated in meters. The abbreviations in the vegetable cover column correspond to MOF - mixed ombrophylous forest and EGL - grass-woody steppe. The abbreviations in the pedology column correspond to RA - Red Argisol and AC - Argilluvic Chernosol.

\begin{tabular}{|c|c|c|c|c|c|c|c|c|c|c|}
\hline $\begin{array}{l}\text { SIT } \\
\text { E }\end{array}$ & $\begin{array}{l}\text { VEGETATION } \\
\text { COVER } \\
\end{array}$ & $\begin{array}{l}\text { ALTIME } \\
\text { TRY }\end{array}$ & SLOPE & & $\begin{array}{l}\text { PEDOL } \\
\text { OGY }\end{array}$ & $\begin{array}{l}\text { DISTANCE WETLANDS } \\
\text { (METERS) }\end{array}$ & $\begin{array}{l}\text { DISTANCE } \\
\text { (METERS) } \\
\end{array}$ & STREAMS & $\begin{array}{l}\text { NEAREST } \\
\text { (METERS) } \\
\end{array}$ & RIVER \\
\hline 1 & MOF & 677 & $\begin{array}{l}16 \% \\
24 \%\end{array}$ & - & RA & 330 & 1600 & & 12000 & \\
\hline 2 & MOF & 718 & $\begin{array}{l}09 \% \\
16 \%\end{array}$ & - & RA & 50 & 700 & & 5200 & \\
\hline 3 & MOF & 738 & $\begin{array}{l}24 \% \\
34 \%\end{array}$ & - & RA & 1200 & 1500 & & 4500 & \\
\hline 4 & MOF & 654 & $\begin{array}{l}16 \% \\
24 \%\end{array}$ & - & RA & 40 & 430 & & 7100 & \\
\hline 5 & MOF & 705 & $0 \%-9$ & & RA & 300 & 2800 & & 3730 & \\
\hline
\end{tabular}




\begin{tabular}{|c|c|c|c|c|c|c|c|}
\hline 6 & MOF & 634 & $0 \%-9 \%$ & RA & 30 & 2000 & 5100 \\
\hline 7 & MOF & 713 & $0 \%-9 \%$ & RA & 100 & 315 & 6300 \\
\hline 8 & MOF & 670 & $\begin{array}{l}16 \% \\
24 \%\end{array}$ & RA & 1250 & 800 & 3960 \\
\hline 9 & MOF & 572 & $\begin{array}{l}24 \% \\
34 \%\end{array}$ & $\mathrm{RA}$ & 2500 & 960 & 960 \\
\hline 10 & MOF & 689 & $\begin{array}{l}16 \% \\
24 \%\end{array}$ & RA & 300 & 900 & 7075 \\
\hline 11 & MOF & 689 & $0 \%-9 \%$ & RA & 60 & 1700 & 11000 \\
\hline 12 & MOF & 702 & $0 \%-9 \%$ & RA & 75 & 1300 & 8520 \\
\hline 13 & MOF & 716 & $0 \%-9 \%$ & RA & 150 & 1700 & 5570 \\
\hline 14 & $\mathrm{EGL}$ & 640 & $\begin{array}{l}16 \% \\
24 \%\end{array}$ & RA & 900 & 1200 & 1200 \\
\hline 15 & EGL & 735 & $\begin{array}{l}16 \% \\
24 \%\end{array}$ & $A C$ & 200 & 2400 & 6500 \\
\hline 16 & EGL & 816 & $\begin{array}{l}09 \% \\
16 \%\end{array}$ & $A C$ & 250 & 600 & 9950 \\
\hline 17 & EGL & 814 & $0 \%-9 \%$ & $A C$ & 200 & 950 & 10450 \\
\hline 18 & EGL & 785 & $0 \%-9 \%$ & $A C$ & 210 & 1200 & 9560 \\
\hline 19 & EGL & 780 & $\begin{array}{l}09 \% \\
16 \%\end{array}$ & $A C$ & 140 & 2000 & 10030 \\
\hline 20 & EGL & 790 & $0 \%-9 \%$ & $A C$ & 50 & 2900 & 8760 \\
\hline 21 & EGL & 711 & $0 \%-9 \%$ & $\mathrm{RA}$ & 120 & 830 & 6200 \\
\hline
\end{tabular}

In order to detect whether the location of the sites has a pre-established pattern in the landscape, a Principal Component Analysis (PCA) was performed. It is a multivariate statistical technique that consists of transforming a set of original variables into another set of variables of the same dimension called principal components (HONGYU et al., 2016). For that, we used data of slope, altimetry and pedology. The PCA meets the requirements listed on archaeological sites by establishing environmental criteria as variables that point to a new range of interpretations. The work was carried out using the software Past v. 3.26 (HAMMER et al., 2001).

In order to verify whether the distances in relation to wetlands, rivers and streams were associated with the location of the site, the data were modeled using a Generalized Linear Model (GLM) and the Poisson distribution. The work was carried out using the software R v. 3.4.0, package stats, function glm.

\section{RESULTS}

The PCA revealed that there is a clear separation of sites according to the characteristics of the landscape. A distinction on the occupation of the territory is perceived from similar characteristics, common to phytophysiognomies. The sites located at the MOF have an average altimetry of $683 \mathrm{~m}$, an average slope between 9-18\%, and a predominance of Red Argisol (RA). The sites located in the Grass-Woody Steppe (EGL) have an average altimetry of $759 \mathrm{~m}$, an average slope between 6-14\%, and a predominance of Argilluvic Chernosol (AC). The areas of MOF have the presence of wetlands and streams in their surroundings. However, they have a characteristic relief and soil. In field areas, where water resources are scarcer, the proximity to wetlands presents itself at a greater proportion.

The modeling using GLM demonstrated an association between the distance from wetlands and the sites located in the different phytophysiognomies $(Z=25.34 ; B=0.64 ; p<0.0001)$, and this distance is shorter at the sites located in the EGL. Compared to the distance from streams, the sites located in EGL are at greater distances than those located in MOF $(Z=-13.51 ; B=-0.16 ; p<0.0001)$. The same pattern is observed for rivers 
$(Z=-42.94 ; B=-0.22 ; p<0.0001)$

The distances from the sites located in mixed rain forest in relation to wetlands, on average, are greater than those located in steppe-grassy areas. Conversely, although not obvious, sites located in the MOF are closer to streams and running water than those located in steppe-grassy areas.

\section{DISCUSSION}

The potential of wetlands associated with the distribution of underground structures has elements that can attest to the use of these ecosystems by the Jê Group.

Wetlands is a generic term used to characterize water-saturated soil ecosystems, such as swamps, wetlands, mangroves and similar areas. These ecosystems occur on all continents (except for Antarctica) and in a wide variety of climatic types (BRINSON et al., 2002). They are ecotonal areas between aquatic and terrestrial ecosystems whose stability and diversity of species are closely conditioned by hydrology and material flows (BEDFORD et al., 2001). Because they occur within a range of climatic, topological and biogeographic combinations, wetlands support an extraordinary richness of plants and animals (KEDDY, 2010; BRINSON et al., 2002). The rich biota is adapted to tolerate alternating periods of presence of water, salinity, $\mathrm{pH}$ and nutrients, forming a highly productive and functionally diversified ecosystem (BENSTEAD et al., 2003).

Lyon et al. (2011) considers wetlands as a mixture of characteristics of terrestrial or aquatic environments which creates a unique habitat for life and its processes. Thus, wetlands can be found almost everywhere. They have characteristics of both environments and a mixture of soil, plant and water conditions that creates a unique habitat for life and its processes. Several groups from the past used the variability of fauna and flora in wetlands. However, they are found in low-lying regions associated with coastal and lagoon environments (DEBLASIS, 2007; ASSUNÇÃO, 2010).

Analyzing the deposits of shells of the Itapeva barrier, on the northern coast of the state of Rio Grande do Sul, Wagner (2009) warned that they are precisely overlapping with dune alignments parallel to the coast, where the Jê probably explored fishing and hunting in small wetlands and freshwater lagoons formed between the streams, complementing their way of life based on the exploration of the marine environment and the collection of mollusks.

Pavei et al. (2015) analyzed fauna components recovered from the archaeological site Sambaqui do Papagaio and found four fragments belonging to Hidrochoerus hidrochoeris (Linnaeus, 1766) (capybara) and one to Cuniculus paca (paca). These animals have semi-aquatic habits and forage in search of grasses and aquatic plants.

Works carried out with groups of knoll builders in the Laguna de Castillos Basin in eastern Uruguay point to a period of desertification that led to a decrease in the average sea level, concomitant with a lagoon descent, which occurred approximately between 5,000 and 2,000 years before present (BP) (CAPDEPONT et al., 2002). This would imply a reduction in plant biomes across the basin, which makes it possible to consider the edges of swamps and lagoons as privileged places for human occupation. This period of dryness led to 
the clogging of the lagoon coast and the concomitant development of shallow water environments. For 1,200 BP, with a sea level gradually approaching the current one, wet and hot conditions are evident (IRIONDO, 1997; CAPDEPONT et al., 2002).

The patterns of settlements recorded in this basin accompanied changes in the landscape, reflecting a strategy that aimed to maximize the exploitation of available resources. This would be documented by the presence of occupations on the immediate plains off the coast of the lagoon in sandy spots that penetrate wet and swampy areas. These points are presented as strategic places of concentration of resources with considerable advantages for occupation (DEL PUERTO, 2004). Hilly structures are located at the highest points of this landscape, prioritizing the topography highlighted symbolically and in terms of the visual domain of the lower areas and the high concentration of resources.

The layout of the sites associated with the knoll builders is similar as the logic identified in the layout of pit houses in the South Brazilian Plateau region. The researchers' analyses contributed to make it even more evident the fact that such occupations were carried out strategically around wetlands, and that the people who built the underground structures sought areas that provided them with safety and natural resources for the group's subsistence (SCHMITZ et al., 2011).

For Corteletti (2008), in his work carried out in the region of Caxias do Sul (RS), the use of wetlands could be associated with the capture of water resources. The author leads us to think about the type of water source used, where $51 \%$ of the sites can make use of spring water, since they are the closest sources. A peculiar situation is that of areas close to wetlands, accounting for $31 \%$ of the total. If we analyze only "pit houses" sites, which are housing settlements, we see that the use of streams increases to $60 \%$ and that of wetlands to $34 \%$.

The work of Cortelleti (2016) in the Urubici/SC/Brazil region, containing an analysis of phytoliths from ceramic fragments evidenced in an underground fire, revealed a large amount of Cyperaceae, particularly of Scirpus "achene bodies." The high frequency of Scirpus may represent the use of reeds as a building material or as a covering material within the structures of pit houses. This plant grows in lotic environments.

According to Kormondy et al. (2002), human populations migrate, change the quality and type of items that make up the diet, or change the way by which they obtain resources to be able to deal with the seasonal fluctuations of the macroenvironment, with the corresponding adjustments in the microenvironment. This has implications in the way they organize themselves socially.

Recalling the data obtained by the multivariate component analysis, the distances from the sites located in the mixed rain forest in relation to wetlands, on average, are more distant than those located in steppe-grassy areas. The analysis shows two distinct sets of sites based on the established criteria. The areas of mixed rain forest have the presence of wetlands and small streams in their surroundings. However, they have a characteristic relief and soil. In field areas, where water resources are scarcer, the proximity of the sites to wetlands appears at a greater proportion.

According to Lieberman et al. (1993), groups can move when the daily costs of foraging in a given region become greater than the costs of moving elsewhere. Therefore, according to these authors, in areas 
with little supply of resources, the groups would tend to move frequently and to camp in the center of the habitats; in environments with a greater diversity of resources, they would almost always be less mobile and would tend to camp close to ecotones, where the resources of various habitats can be allocated in the same location.

Kelly (1983) observed that the fauna in the tropics, savannahs, temperate forests and boreal forests (areas generally with a high primary biomass characterized by tall or coniferous trees or both) presents a greater difficulty of access by hunter groups seeking to obtain conspicuous resources. Animals from environments characterized by high productivity feed on the production locus, tend to have a smaller body size, and are distributed in different vegetation strata.

The region between the Forqueta River and the Guaporé River have sites located exactly in the transition from the mixed rain forest to highland fields. The availability of resources in these areas is rich in diversity and availability. The presence of wetlands reinforces the sense of a habitat that can be properly explored in both vegetation covers.

In his work, Reis (2002) addressed the hierarchy of resources of groups that build pit houses; they would be distributed in three concentric zones. The first zone is around the site; it includes the shelter, a strategic view and immediate access to water; the second zone contains the resources of low mobility, offering safety in movement usually exploited for planting and collecting vegetables and hunting small animals; the third zone, more distant, with greater mobility and the possibility of hunting larger animals.

Within these three categories of resource hierarchy, the wetlands of the present study can be linked to the first and second areas of operation, to where water collection, as well as collection of flora and capture of small fauna, may be associated.

Also, according to Lupo (2007), human groups respond to religion, rituals, hierarchy, art, and personal obligations. Therefore, not all movements of human groups are directly controlled by subsistence. There are also movements of past human populations linked to the function of access to firewood, raw material to produce tools, or due to intolerance to insects. Movements can also be socially or politically motivated.

Recent works have presented a complexification of architectural spaces of the Jê Group (DEMASI 2001; 2007; IRIARTE et al., 2008; CORTELETTI et al., 2015; 2016) with the occupation of adjacent areas. Thus, we can think of wetlands as "borrowing areas" of environmental variability. It composes yet another element in the patch of using areas with potential resources.

\section{CONCLUSIONS}

Wetlands have potential and variability of fauna and flora resources that can be used throughout the year, ensuring the Jê Group another variable in forest management and the use of an ecosystem found in abundance in the studied landscape.

From these conceptions, the investigative intention of elucidating new environmental strategies for the groups of the South Brazilian Plateau is reinforced, where these environments are also noticeable and capable of interaction. 
Wolf (2016) concluded, from the environmental point of view, that the unit analyzed in the present study has a variety of ecotones, which allowed the investigation on the occupation of different spaces. Thus, the distribution of underground structures may be associated with the presence of wetlands

However, as it is an exploratory study, other data must be incorporated, collected and analyzed so that more information can be used in the analyses. This article shows that it is possible to generate consistent information with the existing data capable of making a significant contribution to the use of wwetlands by the Jê Group.

ACKNOWLEDGEMENTS: We would like to thank CAPES (Coordenação de Aperfeiçoamento de Pessoal de Nível Superior) for the doctoral scholarship to JF through the Community IES Postgraduate Support Program (PROSUC) (\# 97872326000) and the postdoctoral scholarship through the National Postdoctoral Program (PNPD) to MSD (2018). We would also like to thank CNPQ (Conselho Nacional de Desenvolvimento Científico e Tecnológico) for the Research Productivity Grant to NGM (\#310966/2017-5) and postdoctoral scholarship to MSD (2019 - \#153902/2018-3). The fieldwork of this research were financed with the support of FAPERGS (Fundação de Amparo à pesquisa do Estado do RS) Pesquisador Gaucho Program (05/2019 - \#19/25510001768-5) and Universidade do Vale do Taquari - UNIVATES.

\section{REFERENCES}

ADAMS, C.; MURRIETA, R.; NEVES, W. A.. Sociedades caboclas amazônicas: modernidade e invisibilidade. São Paulo: Annablume, 2006.

ARAÚJO, A. G. M.. A Tradição Cerâmica Itararé-Taquara: Características, área de ocorrência e algumas hipóteses sobre a expansão dos grupos Jê no sudeste do Brasil. Revista de Arqueologia, v.20, p.9-38, 2007.

\section{ARAÚJO, A. G. M.. Teoria e método em arqueologia} regional: um estudo de caso no alto Paranapanema, Estado de São Paulo. Tese (Doutorado) - Universidade de São Paulo, São Paulo, 2001.

ASSUNÇÃO, D. C.. Sambaquis da paleolaguna de Santa Marta: em busca do contexto regional no litoral sul de Santa Catarina. Tese (Doutorado) - Universidade de São Paulo, São Paulo, 2010.

BEBER, M. V.. O sistema de assentamento dos grupos ceramistas do Planalto Sul-brasileiro: o caso da Tradição Taquara/Itararé. Arqueologia do Rio Grande do Sul, Brasil, Documentos. IAP-UNISINOS, v.10, p.5-125, 2005.

BEDFORD, B. L.; LEOPOLD, D. J.; GIBBS, J. P.. Wetlands ecosystems. In: LEVIN, S. A.. Encyclopedia of biodiversity. 2001. p.384-402. DOI: https://doi.org/10.1016/B978-0-12384719-5.00314-2

BENSTEAD, J. P.; DOUGLAS, M. M.; PRINGLE, C. M.. Relationships of stream invertebrate communities to deforestation in eastern Madagascar. Ecological Applications, v.13, n.5, p.1473-1490, 2003. DOI: https://doi.org/10.1890/02-5125
BRINSON, M. M.; MALVÁREZ, A. I.. Temperate freshwater wetlands: types, status, and threats. Environmental conservation, v.29, n.2, p.115-133, 2002.

BUTZER, K. W.. Archaeology as human ecology: method and theory for a contextual approach. Cambridge University Press, 1982.

CAPDEPONT, I.; INDA, H.; DEL PUERTO, L.. Caracterización Tecnológica y Funcional del material cerámico arqueológico de la Cuenca de la Laguna de Castillos (Rocha-Uruguay). In: MAZZANTIN, D. M. B.; OLIVA, F.. Del mar a los salitrales: Diez mil años de historia Pampeana en el umbral del tercer milenio. Mar del Plata: Facultad de Humanidades, 2002. p.41-50.

CASTRO, F.. Níveis de decisão e o manejo de recursos pesqueiros. In: BEGOSSI, A.. Ecologia de pescadores da Mata Atlântica e da Amazônia. São Paulo: Fapesp, 2004. p.255284.

COPÉ, S. M.. A gênese das paisagens culturais do planalto sul brasileiro. Estudos avançados, v.29, n.83, p.149-171, 2015. DOI: http://dx.doi.org/10.1590/S0103-40142015000100007

COPÉ, S. M.. Les grands constructeurs précoloniaux du plateau du sud du Brésil: étude de paysages archéologiques à Bom Jesus, Rio Grande do Sul, Brésil. Thesis (PHD) Université de Paris I. Panthéon, Sorbonne, 2006a.

COPÉ, S. M.. Narrativas espaciais das ações humanas: História e aplicação da arqueologia espacial como teoria de médio alcance: o caso das estruturas semi-subterrâneas do planalto Sul-brasileiro. Revista de Arqueologia, v.19, n.1 p.111-123, 2006b. DOI: 
https://doi.org/10.24885/sab.v19i1.218

CORTELETTI, R.. Patrimônio arqueológico de Caxias do Sul. Nova Prova, 2008.

CORTELETTI, R.; DEBLASIS, P.. Arqueologia Jê do Sul do Brasil: ambiente, sistema, poder e experiência na paisagem de Urubici, Santa Satarina. Revista Memorare, v.5, n.2, p.132-164, 2018. DOI: http://dx.doi.org/10.19177/memorare.v5e22018132-164

CORTELETTI, R.; DICKAU, R.; DEBLASIS, P.; IRIARTE, J.. Revisiting the economy and mobility of southern proto-Jê (Taquara-Itararé) groups in the southern Brazilian highlands: starch grain and phytoliths analyses from the Bonin site, Urubici, Brazil. Journal of Archaeological Science, v.58, p.4661, 2015. DOI: https://doi.org/10.1016/j.jas.2015.03.017

CORTELETTI, R.; DICKAU, R.; DEBLASIS, P.; IRIARTE, J.. Analises de grãos de amido e fitólitos nas terras altas do sul do Brasil: repensando a economia e mobilidade dos grupos proto-Jê meridionais. Cadernos do LEPAARQ (UFPEL), v.13, n.25, p.162-196, 2016

DEAGAN, K. A.. Environmental archaeology and historical archaeology. In: REITZ, E. J.; SCUDDER, S. J.; SCARRY, C. M.. Case Studies in Environmental Archaeology. Interdisciplinary Contributions to Archaeology. New York: Springer, 2008. p.21-42. DOI: https://doi.org/10.1007/978-0387-71303-8 2

DEBLASIS, P.; KNEIP, A.; SCHEEL-YBERT, R.; GIANNINI, P. C.; GASPAR, M. D.. Sambaquis e paisagem: dinâmica natural e arqueologia regional no litoral do sul do Brasil. Arqueologia suramericana, v.3, n.1, p.29-61, 2007.

\section{DEL PUERTO, L.. Ponderación de recursos vegetales y} análisis arqueobotánico para el este del Uruguay. Universidad de la República, 2003.

DEMASI, M. A.. Projeto de salvamento arqueológico usina hidrelétrica de Campos Novos. Relatório final. Tubarão, Unisul, 2005.

DEMASI, M. A. N.. Pescadores coletores da costa sul do Brasil. Pesquisas Antropologia, n.57, p.3-136, 2001.

DIAS, A. S.. Sistemas de assentamento e estilo tecnológico: uma proposta interpretativa para a ocupação pré-colonial do alto vale do rio dos Sinos, Rio Grande do Sul. Tese (Doutorado) - Universidade de São Paulo, São Paulo, 2003.

DROUIN, J.-M.. L'écologie et son histoire. Réinventer la nature. Paris: Flammarion, 1991.

EVANS, J. G.. An introduction to environmental archaeology. Ithaca: Cornell University Press, 1978.

GETZNER, M.. The quantitative and qualitative impacts of clean technologies on employment. Journal of Cleaner Production, v.10, n.4, p.305-319, 2002. DOI: https://doi.org/10.1016/S0959-6526(01)00042-7

HAMMER, $\varnothing$.; HARPER, D. A.; RYAN, P. D.. PAST: Paleontological statistics software package for education and data analysis. Palaeontologia Eletrônica, v.4, n.1, p.9, 2001.
HONGYU, K.; SANDANIELO, V. L. M.; OLIVEIRA JUNIOR, G. J.. Análise de componentes principais: resumo teórico, aplicação e interpretação. E\&S Engineering and Science, v.5, n.1, p.83-90, 2016. DOI:

http://dx.doi.org/10.18607/ES201653398

IBGE. Instituto Brasileiro de Geografia e Estatística. Projeto redes e fluxos no território: as ligações aéreas. IBGE, 2010.

IRIARTE, J.; GILLAM, J. C.; MAROZZI, O.. Monumental burials and memorial feasting: an example from the southern Brazilian highlands. Antiquity, v.82, n.318, p.947-961, 2008. DOI: https://doi.org/10.1017/S0003598X00097702

IRIONDO, MARTIN; KRÖHLING, D.. The tropical loess. In: INTERNATIONAL GEOLOGICAL CONGRESS, 30. Anais. International Union of Geological Sciences Beijing, 1997. p.61-77.

KEDDY, P. A.. Wetland ecology: principles and conservation. Cambridge University Press, 2010.

KELLY, R. L.. Hunter-gatherer mobility strategies. Journal of Anthropological Research, v.39, n.3, p.277-306, 1983.

KORMONDY, E. J.; BROWN, D. E.. Ecologia Humana. São Paulo: Atheneu, 2002.

KREUTZ, M. R.. Movimentações de populações Guarani, séculos XIII ao XVIII: Bacia Hidrográfica do Rio Taquari, Rio Grande do Sul. Tese (Doutorado) - Universidade do Vale do Taquari, Lajeado, 2015.

LADURIE, E. L. R.. Historia del clima desde el año mil. Fondo de Cultura Económica, 1991.

LIEBERMAN, D.; BELFER-COHEN, A.; HENRY, D. O.; KAUFMAN, D.; MACKIE, Q.; OLZEWZKI, D.; ROCEK, T.; SHEPPARD, P.; TRINKAUS, E.; VALLA, F.. The rise and fall of seasonal mobility among hunter-gatherers: the case of the southern Levant [and comments and replies. Current Anthropology, v.34, n.5, p.599-631, 1993.

LUPO, K. D.. Evolutionary foraging models in zooarchaeological analysis: recent applications and future challenges. Journal of Archaeological Research, v.15, n.2, p.143-189, 2007.

LYON, J. G.; LYON, L. K.. Practical handbook for wetland identification and delineation. CRC Press, 2011.

MACHADO, N. T. G.; MILDER, S. E. S.. Prospecções arqueológicas e físico-químicas no sítio RS T 100: estruturas em San Valentin-Ilópolis-RS. In: COLÓQUIO SOBRE SÍTIOS CONSTRUÍDOS: CASAS SUBTERRÂNEAS, 1. Anais. Santa Maria: Pallotti, 2005.

MARTINS, P. S.. Biodiversity and agricuture: patterns of domestication of Brazilian native plant species. Anais da Academia Brasileira de Ciências, v.66, n1-2, 1994.

MORAN, E. F.. Adaptabilidade Humana: uma Introdução à Antropologia Ecológica. São Paulo: Edusp, 1994.

NOELLI, F. S.. O mapa arqueológico dos povos Jê do Sul do Brasil. In: TOMMASINO, K.; MOTTA L. T.; NOELLI F. S.. Novas 
contribuições aos estudos interdisciplinares dos Kaingang. Londrina: Eduel, 2004. p.17-55.

NOVASCO, R. V.; SCHMITZ, P. I.. Estratégias de assentamento: uma análise sobre o sítio arqueológico Rincão dos Albinos, Planalto de Santa CatarinaBrasil. Revista do Museu de Arqueologia e Etnologia, n.27, p.213-225, 2016. DOI: https://doi.org/10.11606/issn.24481750.revmae.2016.137347

PAVEI, D. D.; CAMPOS, J. B.; ZOCCHE, J. J.; SANTOS, M. C. P.. Zooarqueologia de Vertebrados do Sambaqui do Papagaio, Bombinhas, Santa Catarina. Tecnologia e Ambiente, v.21, p.70-89, 2015. DOI: http://dx.doi.org/10.18616/ta.v21i0.1928

PÉRICO, E.; AREND, U.; CEMIN, G.; ECKHARDT, R.; SECCHI, F.; REMPEL, C.. Alterações na paisagem da Bacia Hidrográfica do Rio Forqueta, RS, Brasil. In: SIMPÓSIO BRASILEIRO DE SENSORIAMENTO REMOTO, 15. Anais. São Paulo: INPE, 2011. p.1713-1719.

REIS, J. A.. Arqueologia dos buracos de bugre: uma préhistória do planalto meridional. Caxias do Sul: Educs, 2002.

REIS, J. A.. Para uma Arqueologia dos buracos de bugre: do sintetizar, do problematizar, do propor. Dissertação (Mestrado) - Pontifícia Universidade Católica do Rio Grande do Sul, Porto Alegre, 1997.

REIS, M. J.. A problemática arqueológica das estruturas subterrâneas no planalto catarinense. Dissertação (Mestrado) - Universidade de São Paulo, São Paulo, 1980.

REIS, M. J.. A problemática arqueológica das estruturas subterrâneas no planalto catarinense. Erechim: Habilis, 2007.

REITZ, E. J.; NEWSOM, L. A.; SCUDDER, S. J.. Issues in environmental archaeology. In: REITZ, E. J.; NEWSOM, L. A.; SCUDDER, S. J.. Case studies in environmental archaeology. New York: Plenum Pres, 1996. p.3-16.

RENFREW, C.; BAHN, P.. Arqueologia, Teoria, Métodos y Prácticas. Madrid: Akal, 1993.

ROBRAHN, E. M.. A ocupação pré-colonial do vale do rio Ribeira de Iguape, São Paulo: os grupos ceramistas do médio curso. Dissertação (Mestrado) - Universidade de São Paulo, São Paulo, 1989.

ROGGE, J. H.; SCHMITZ, P. I.. Pesquisas arqueológicas em São Marcos, RS. Pesquisas Antropologia, v.67, p.23-132, 2009.

SALDANHA, J. D. M.. Paisagem, lugares e cultura material: uma arqueologia espacial nas terras altas do sul do Brasil. Dissertação (Mestrado) - Pontifícia Universidade
Católica do Rio Grande do Sul, Porto Alegre, 2005.

SCHMITZ, P. I.; BECKER, Í. B.. Os primitivos engenheiros do Planalto e suas estruturas subterrâneas: a tradição Taquara. In: SCHMITZ, P. I.. Arqueologia do Rio Grande do Sul/Brasil. Documentos, v.5, n.2, p.125-148, 1991.

SCHMITZ, P. I.; NOVASCO, R. V.. Arqueologia no planalto: o uso do SIG na aplicação de análises espaciais dos sítios arqueológicos da localidade Boa Parada, Município de São José do Cerrito, SC. Revista do Museu de Arqueologia e Etnologia, n.21, p.167-183, 2011a. DOI: https://doi.org/10.11606/issn.24481750.revmae.2011.89971

SCHMITZ, P. I.; ROGGE, J. H.. 107 'casas subterrâneas' no início do povoamento Jê Meridional em Santa Catarina: Rincão dos Albinos. Revista do Museu de Arqueologia e Etnologia, n.21, p.185-204, 2011b. DOI: https://doi.org/10.11606/issn.24481750.revmae.2011.89972

SCHUTKOWSKI, H.. Human ecology: biocultural adaptations in human communities. Springer Science \& Business Media, 2006.

SIEMENS, A. H.. Extrayendo ecología de algunos documentos novohispanos de la época temprana. In: GARCIA, B.; JÁCOME, A.. Estudios sobre historia y ambiente en América I. 1999. p.219-264.

SOUZA, J. G.; CORTELETTI, R.; ROBINSON, M.; IRIARTE, J.. The genesis of monuments: Resisting outsiders in the contested landscapes of southern Brazil. Journal of Anthropological Archaeology, v.41, p.196-212, 2016a. DOI: https://doi.org/10.1016/j.jaa.2016.01.003

SOUZA, J. G.; ROBINSON, M.; CORTELETTI, R.; CÁRDENAS, M. L.; WOLF, S.; IRIARTE, J.; MAYLE, F.; DEBLASIS, P. Understanding the chronology and occupation dynamics of oversized pit houses in the southern Brazilian highlands. PloS One, v.11, n.7, p.e0158127, 2016b. DOI: https://doi.org/10.1371/journal.pone.0158127

TEIXEIRA, M. B.; NETO, A. B. C.. Vegetação. In: IBGE. Instituto Brasileiro de Geografia e Estatística. Levantamento de Recursos Naturais. Rio de Janeiro: IBGE, 1986. p.541-632.

WOLF, S.. Arqueologia Jê no Alto Forqueta e Guaporé/RS: um novo cenário para um antigo contexto. Tese (Doutorado) - Universidade do Vale do Taquari, Lajeado, 2016.

WORSTER, D.. Transformações da terra: para uma perspectiva agroecológica na história. Ambiente \& sociedade, v.5, n.2, p.23-44, 2003. DOI: https://doi.org/10.1590/S1414-753X2003000200003

A CBPC - Companhia Brasileira de Produção Científica (CNPJ: 11.221.422/0001-03) detém os direitos materiais desta publicação. Os direitos referem-se à publicação do trabalho em qualquer parte do mundo, incluindo os direitos às renovações, expansões e disseminações da contribuição, bem como outros direitos subsidiários. Todos os trabalhos publicados eletronicamente poderão posteriormente ser publicados em coletâneas impressas sob coordenação da Sustenere Publishing, da Companhia Brasileira de Produção Científica e seus parceiros autorizados. Os (as) autores (as) preservam os direitos autorais, mas não têm permissão para a publicação da contribuição em outro meio, impresso ou digital, em português ou em tradução. 